\title{
Quality of Higher Education through the Pursuit of Satisfaction with a Focus on Sustainability
}

\author{
María del Carmen Olmos-Gómez ${ }^{1, * \mathbb{C}}$, Mónica Luque Suárez ${ }^{2, *}$, Concetta Ferrara ${ }^{1,3}$ and \\ Eva María Olmedo-Moreno 4 (D) \\ 1 Department of Research Methods and Diagnosis in Education, Faculty of Education and Sport Science, \\ University of Granada, 52005 Melilla, Spain; concetta.ferrara@istruzione.it \\ 2 Department of Sociology, Faculty of Education and Sport Science, University of Granada, 52005 Melilla, \\ Spain \\ 3 Associazione Culturale Italiana Per La Formazione, A.C.I.F. University of Naples, Via Salvatore \\ Gambardella, 19, 80145 Napoli NA, Italy \\ 4 Department of Research Methods and Diagnosis in Education, Faculty of Education Science, University of \\ Granada, 18071 Granada, Spain; emolmedo@ugr.es \\ * Correspondence: mcolmos@ugr.es (M.d.C.O.-G.); mlsuarez@ugr.es (M.L.S.)
}

Received: 10 February 2020; Accepted: 17 March 2020; Published: 18 March 2020

check for updates

\begin{abstract}
The objective of this study is to analyse individual differences in quality of higher education through the pursuit of satisfaction with a focus on sustainability, whilst considering variables pertaining to groups (family, teachers and pupils) and satisfaction in a sample of 1091 Italians: 510 pupils (45.8\%), 121 teachers (11.1\%) and 469 relatives (42.9\%). Once the quality parameters of the instrument (quality of higher education through the pursuit of satisfaction with a focus on the sustainability (QHES) questionnaire) were determined, reliability was confirmed through confirmatory factor analysis using structural equation modelling methodology, and data collection was initiated. Results from the multi-level study (ANOVA) showed significant differences between groups. From this, it can be concluded from the study that the role performed by a quality education oriented towards sustainability equally includes teachers, students and relatives. This role focuses on the battle to incorporate effective participatory methods into the teaching process, motivating members of the educational community and social future in the search for knowledge, skills, attitudes and necessary values. This will forge a sustainable future given that it does not only depend on the characteristics and experiences of individuals but also their training, both within the centre and their families. This factor is of vital importance, as demonstrated and concluded in the present study.
\end{abstract}

Keywords: quality; sustainability; satisfaction; family; higher education

\section{Introduction}

Quality is a vitally important concept in current society [1,2], given that we are capable of achieving an optimal use of resources through the creation of quality evaluation. Education forms an essential part of society and obtaining a quality education is the pillar from which sustainable development is based [3]. This is evident, given that the future of society's citizens will play out in accordance with the educational development they undergo. For this reason, the optimisation, improvement and development of mechanisms which guarantee educational quality and, especially, the quality of higher education, will assist future citizens who find themselves in a transitional period with regards to training for the world of work. This is also crucial for social development. Quality is supported through mechanisms which enable regulation of effectiveness, efficiency, functionality and reliability of the evaluated process. This, by definition, forms the basis from which the quality of any type of activity 
can be preserved and improved [4]. In the present day, quality control systems are normally applied in all areas relevant to society: Governmental programs, business activities, urban development, transport and food, and so on [5]. In recent years, not a single area of social action has remained untouched by quality control systems and, of course, the field of education is no exception [6-8].

The concept of quality in higher education can have multiple focuses or meanings, with this being reflected in the literature. Amongst the most common focuses, three are highlighted: Those that centre on the idea of service, those that explore quality from the student's perspective, and those that approach this concept from the teacher's perspective.

The first focus refers to service quality. This concept has received a great deal of attention from a research perspective in the educational sector and at an international level [9-13]. The concept has also been employed to improve service from an objective and subjective point of view, with the outcome being improved client interaction with the service being provided. Preliminary studies from the educational sector suggest that the concept of quality in higher education in the present day has become blurred [14], with different meanings being attributed [15].

In the same sense, Lago, López, Municio, Ospina and Vergara [16] state that quality is the outcome of comparing expectations of a service with the perception of the actual service received. This means that the measurement of quality lies in the satisfaction of individuals and in the value that they believe they receive. Authors such as Carvalho and de Oliveira [17-19] explain that educational model dynamics place the student as the recipient of education and, as a result, converts them into the client receiving the service, with the second and third focuses (student and teacher) being encompassed by the first (service).

The apparently identical concepts of sustainability and sustainable development are topics that currently dominate the continuing global social development of discourse. This is due to the lack of broadly accepted definitions and a variety of viewpoints regarding their real connotations $[20,21]$. As indicated by Boström [22], the present study is based on the description of sustainability as a state of utopia, whilst sustainable development consists of the necessary steps to reach this state. Thus, within the limits of higher education institutions, it refers to the desire to achieve a sustainable university status in relation to sustainability (utopic state). This occurs through their internal processes, with the product of said processes and commitment to society giving shape to sustainable development, which advances towards the implementation of sustainability $[23,24]$

According to the declarations of [25], a sustainable higher education institute is one that values the quality of teaching, implements practices destined to improve the quality of academic life and is concerned with managing its use of natural resources. With regards to the scientific literature identified on the topic, studies have been directed towards the examination of student satisfaction and the quality of the service offered [26], and comes from around the world [27-29]. Research studies have also focused on the value of the educational service offered to the student $[13,17,18,30]$, whilst others understand satisfaction as an emotional response that comes from cognitive judgements [31].

Nevertheless, there are very few research studies that enable us to see the moderating effect of the quality of higher education on satisfaction. Given this, the present research is based on measuring student satisfaction with their educational centre, and the opinions of teachers and family members [32].

According to Mateo [1], this growing interest in quality control within the educational field is determined by the development of a new management paradigm. This paradigm is based on educational actions that pursue the achievement of previously defined objectives. It also involves internal audits to evaluate the extent of the achievement reached, with regards to objectives established at the start and the possibility of elevating decision making to a higher level where strategic sustainability skills are involved.

At the root of that previously discussed, when discussing the quality indicators that determine student satisfaction, authors such as Resino, Chamizo, Cano and Gutiérrez [33] highlight three focuses: resources and facilities, academic aspects and social aspects. Thus, in the present work, we will analyse student perceptions about the quality of services received from their educational institution 
and examine the quality dimension through the use of physical infrastructure and resources. This is done in order to support educational quality in a sustainable way, ensuring that future generations will also reap the benefits. It seeks to guarantee the sustainability of better quality [34] knowledge transmission processes carried out by teachers and integral development promoted in students, academic programs [35], and families.

As we can observe, the quality of teaching has become an important strategic issue in higher education [36,37]. We find ourselves embroiled in initiatives that have been developed to analyse and satisfy the needs of interested parties in general; in other words, families, institutions, teaching staff and students [38]. DiDomenico and Bonnici [39] argue that higher education institutions must analyse the quality of service offered in order to be able to function effectively and efficiently within a competitive environment, whilst also making efforts to define a strategy focused on the need satisfaction of clients $[40,41]$. The Bolonia process has made this a reality by accelerating the introduction and elaboration of quality assurance, taking both an institutionalized approach and making use of quality management mechanisms [42].

The present research study is developed in Italy and, just like in other countries, it is carried out through student evaluations, with these students being considered as "consumers". Globalised competition has emphasised the strategic importance of satisfaction and quality in the battle for winning over the preferences of consumers and maintaining sustainability but with competitive advantages. This is important given that universities are moving towards a focus that is more directed towards market values [43-45].

The challenge for institutions is to understand and channel their resources in order to achieve client satisfaction [46]. This very satisfaction provides a quality barometer for educational services [47]. Thus, to investigate educational quality is to invest in the future, given that, with this, we can optimise resources and realise sustainable development for future generations.

Based on the previous analysis, the objectives and the novelty of the present study are as follows:

(1) To design and validate an instrument to analyse the impact of higher education quality through the pursuit of satisfaction with a focus on sustainability, according to the groups (family, pupils and teachers) of participants involved in higher education. This is relevant because no instruments currently exist which examine quality whilst taking a sustainability focus.

(2) To determine the possible associations between quality through the pursuit of satisfaction with a focus on sustainability and the variables of groups and satisfaction.

\section{Materials and Methods}

\subsection{Method}

In the present research, a quantitative-descriptive study was conducted based on the social analytical-empirical research method [48].

\subsection{Participants}

We analysed the associations between general satisfaction, groups (families, students and teachers) and educational quality in higher education as it related to students, families and teachers selected through random sampling. Sixteen groups were selected (from a total of 21) from higher education student groups from the south of Italy (Naples, Italy). Participants came from the University of Naples and were selected through random sampling. Sampling followed a random selection of one class from each year undertaking courses at the selected institution. Naples is the most highly populated city located in the southern region of Italy. It is known as the capital of the Campania region and the metropolitan city of Naples. Just under one million inhabitants live within the area delimited within the municipality of Naples. It is located between Mount Vesuvius and the Phlegraean Fields. It has enormous historical, artistic, cultural and gastronomic wealth, which led UNESCO to declare its historical centre as a world heritage site. It was briefly under Austrian rule in the early decades of the 
18th century. Following this, it was converted into the political centre of the independent kingdom of Naples and, later, part of the Two Sicilies governed by the Bourbons (Spanish). For this reason, it has strong Spanish resemblances.

In total, $N=1091$ students, fathers and teachers participated in the present study. The entire sample was selected using non-probabilistic sampling (convenience), with the questionnaire being administered to those who indicated a desire to participate. Sample distribution consisted of 510 students $(45.8 \%)$, 121 teachers $(11.1 \%)$ and 469 relatives $(42.9 \%)$. The age of participants ranged between 17 and 25 years old (mean $=19.84$ years). The age of participating teachers ranged between 35 and 45 years old (mean $=38.5$ years). The age of participants who were relatives of students ranged between 50 and 65 years old (mean $=55.9$ years). The participating sample constituted $86 \%$ of the overall sample of individuals undertaking higher education in the region of southern Italy.

\subsection{Instrument}

Each participant received the questionnaire developed for the present study, which was based on previously developed questionnaires [33,36,37]. The tool design was aligned with the main theoretical guidelines for building tests (the American Association of Educational research, the American Association of Psychology and the National Council for Educational Evaluation 2014) Responses should be rated on a continuum of 1 to 5 from "I don't agree" to "I always agree". To test the understanding and clarity of the items included, the first version of the questionnaire was administered in a centre of higher education. After the pilot run, modifications were made to the initial design, eliminating those items that had been detected as difficult to understand, which were three of the 49 original items in the questionnaire. The tool worked on basic principles taken from other international models of quality evaluation and satisfaction, such as those of Sweden or Italy, based on educational philosophy and curriculum design with a marked focus on the value of work and the sense of all teaching efforts, which was shortened and adapted to the context of Southern Italy and further modified to incorporate the variable describing satisfaction. As an initial focus in selecting the items to be included in the questionnaire, a group of students $(n=501)$, with similar characteristics to the sample used in the present study, were asked to indicate all the items with which they most identified. After collecting this information and following the process of content validity, the questionnaire was analyzed using an expert panel process. Subsequently, 20 experts assessed the instrument using Delphi's method [49]. They signaled any item that they deemed to be poorly written, in addition to indicating its congruence, adequacy and belonging. All the members of the expert panel were PhD holders and were experts in the field of investigation related to the present research. All members of the expert panel held positions in the university context and were experts in the field of investigation at the heart of the present research. Specifically, there were twenty judges who evaluated the instrument. They signalled any item that they deemed to be unclear or badly written, in addition to suggesting recommendations regarding its relevance, congruence and adequacy. Here we will present the professional profile of all of the judges who participated in the process: 7 Doctors $(\mathrm{PhD})$ belonging to the Department of Research Methods and Diagnostics in Education at the University of Granada; 4 Doctors (PhD) belonging to the Department of Research Methods and Diagnostics in Education at the University of Granada (Campus of Melilla); 3 Doctors (PhD) belonging to the Department of Evolutionary Psychology and of Education at the University of Granada; 2 Doctors (PhD) belonging to the Department of Didactics of the Social Sciences at the University of Granada and four Doctors (PhD) belonging to the Department of Didactics and School Organization at the University of Granada [49] The final version of the adapted instrument was developed in the exploratory phase. To this end, three rounds of analyses were conducted amongst the experts. The percentage of agreement within the first round of discussions was in $79 \%, 82 \%$ in the second round, and $90 \%$ in the third round.

Those items whose agreement percentage amongst the expert panel from was $\geq 80 \%$ were modified, eliminated, or regrouped. Following the application of this method, most elements were not significantly modified, although four were completely eliminated. This means that the final 
questionnaire included 46 questions divided between five dimensions (factors). The survey instrument was divided into two parts. In the first part, participants were requested to provide their personal information, including pertinence and reference groups, sex, age, and religion. The second part included questions about the frequency with which participants' opinions manifested with respect to the items expressed. A 5-point scale was used that ranged from $1=\mathrm{I}$ don't agree, to $5=\mathrm{I}$ always agree. An exploratory factorial analysis (EFA) was applied to examine the instruments' construct validity. To guarantee the validity and reliability of the instrument, a factorial analysis of the variables was then completed. The objective of this exploratory study was to estimate the validity of the questionnaire. To validate the instrument, the Kaiser-Meyer-Olkin (KMO) index was calculated. A KMO value above 0.5 is considered to be acceptable. The KMO index here was 0.979 . Hence, the coefficient was close to achieving singularity and was sufficient to proceed to the next step in analyzing the validity and reliability of the test. Using the test of sphericity, we ensured that the level of significance was adequate. The value obtained was 0.000 , which enabled us to proceed with the factorial analysis. Finally, from the table of variance for the rotated component matrix, we were able to obtain the variance outcomes for all the analyzed variables. The outcomes from the previously described analysis identified the existence of five factors that, when combined, explained $70.757 \%$ of the variance.

We estimated the reliability of scores provided on the scale using tests for ordinal data [50], producing a Cronbach alpha of 0.979 .

Next, with the intention of verifying the internal consistency of the preliminary exploratory factor analysis, a confirmatory factor analysis was performed. Each agglomerated component was obtained as a latent variable and the various elements associated with each factor as observable variables.

Subsequently, confirmatory factor analysis (CFA) using the structural equation modeling (SEM) methodology, through which we examined the multivariate regression coefficients based on structural equations [51], which examined the multivariate regression coefficient produced from structural equations. Evaluation of the fit of the data to the model was conducted according to multiple criteria: $\chi 2 / \mathrm{df}$, comparative fit index (CFI) and root mean square error approximation (RMSEA). The literature suggests that fit can be considered to be adequate when $\chi 2 / \mathrm{df}<5$, CFI $>0.90$ and RMSEA $<0.08$ [52]. The data were analysed through statistical software packages SPSS 20 (International Business Machines Corporation (IBM), Chicago, IL, USA, 2011), LISREL v9.1 (Scientific Software International, Princeton, NJ, USA, 2010), and PANTH GRAHF (Scientific Software International, Princeton, New Jersey, 2010) [53].

The results of the CFA confirm the adequate fit of the data to the model (Figure 1). This model originates from both exploratory factors and a theoretical model. The parsimonious fit was $\chi 2 / \mathrm{df}$ $=4170.47 / 989 p<0.001$, A model was formed with 90 degrees of freedom (df) with a maximum likelihood. The $p$-value was less than 0.05; CFI (comparative adjustment goodness index) $=0.87$; RMSEA (root mean square error of approximation) [54] $=0.074(90 \% \mathrm{CI}=0.053-0.080)$. Although the scores produced were adequate when one factor was eliminated, it is necessary to examine a number of other indices. The most interesting of these is the root mean square error approximation (RMSEA), which was slightly below the critical limit: 0.080 . For this reason, the focus is shifted to the adjusted model. The examination of the CFA was conducted using SEM methodology via path analysis. Likewise, the mean square approximation root error (RMSEA) reflects a value of 0.74 being the correct interpretation. Just as can be observed in Figure 1, all of the regression weights were higher than 0.05 , whilst covariance between factors ranged between 0.12 and 1.00 . The evaluation conducted according to the SEM methodology verifies that the derived coefficients show positive agreement with the theory employed to configure the measurement model, with the exception of one weakly linked value [55]. Analysis of the multivariate regression coefficients was conducted through the examination of the covariance matrix of the observed variables. The program Lisrel 9.1 was used to carry this out. The observed and latent variables are formed as follows (Figure 2), in the optionality of confirmatory factorial analysis, in order to analyze the covariance matrix of observable variables. The regression coefficients between the observed and latent variables were represented as 
follows: Factor 1-management of higher education and teaching resources; Factor 2-coordination of educational activities in higher education; Factor 3-management of teaching in higher education through knowledge of the topics included in the study program, and delivery of a planned timetable in order to meet program objectives and the evaluation system; Factor 4-teacher planning and teaching staff in higher education.

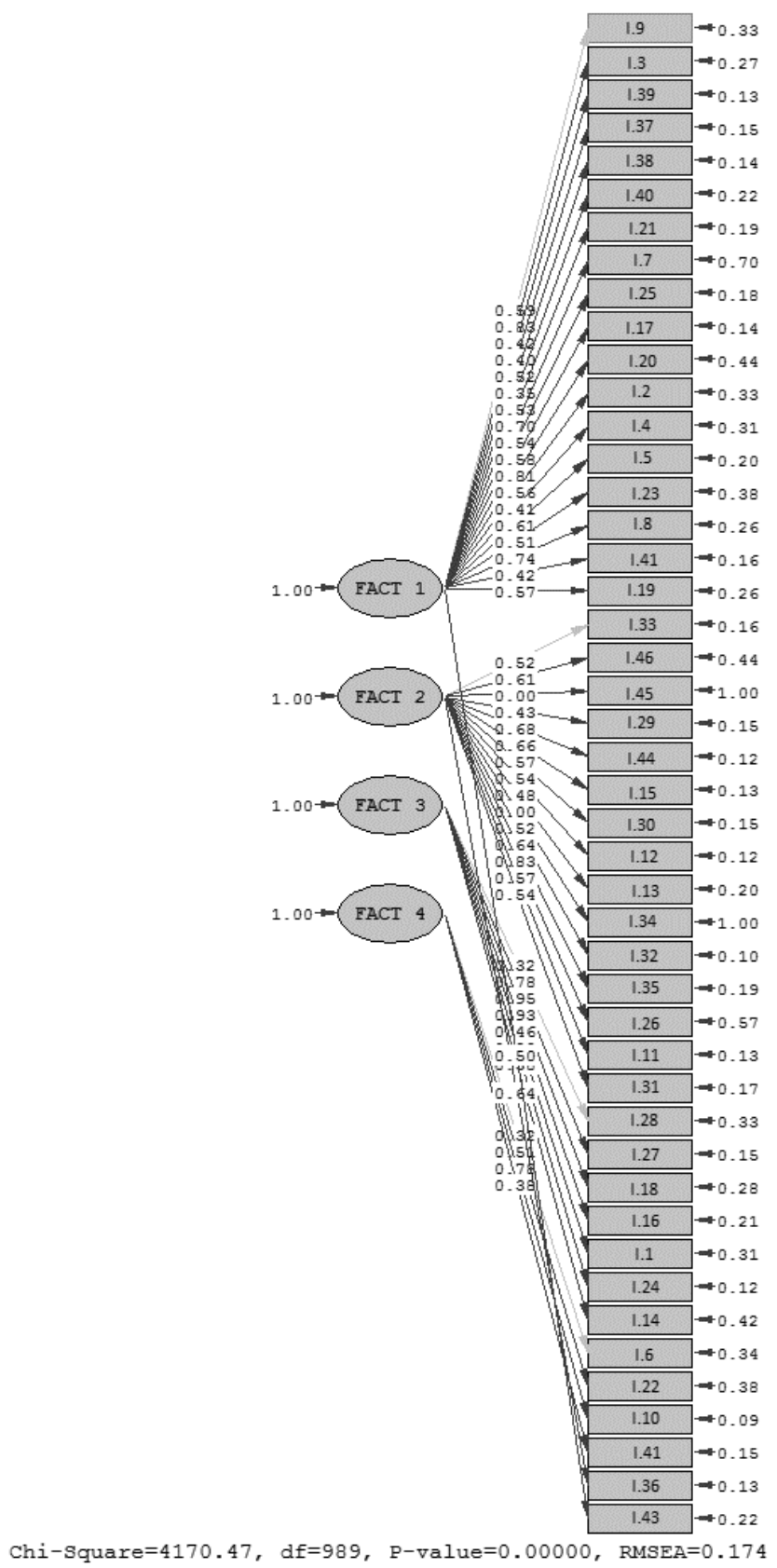

Figure 1. Schematic (path graph) of the quality of higher education through the pursuit of satisfaction with a focus on sustainability (QHES) questionnaire. 


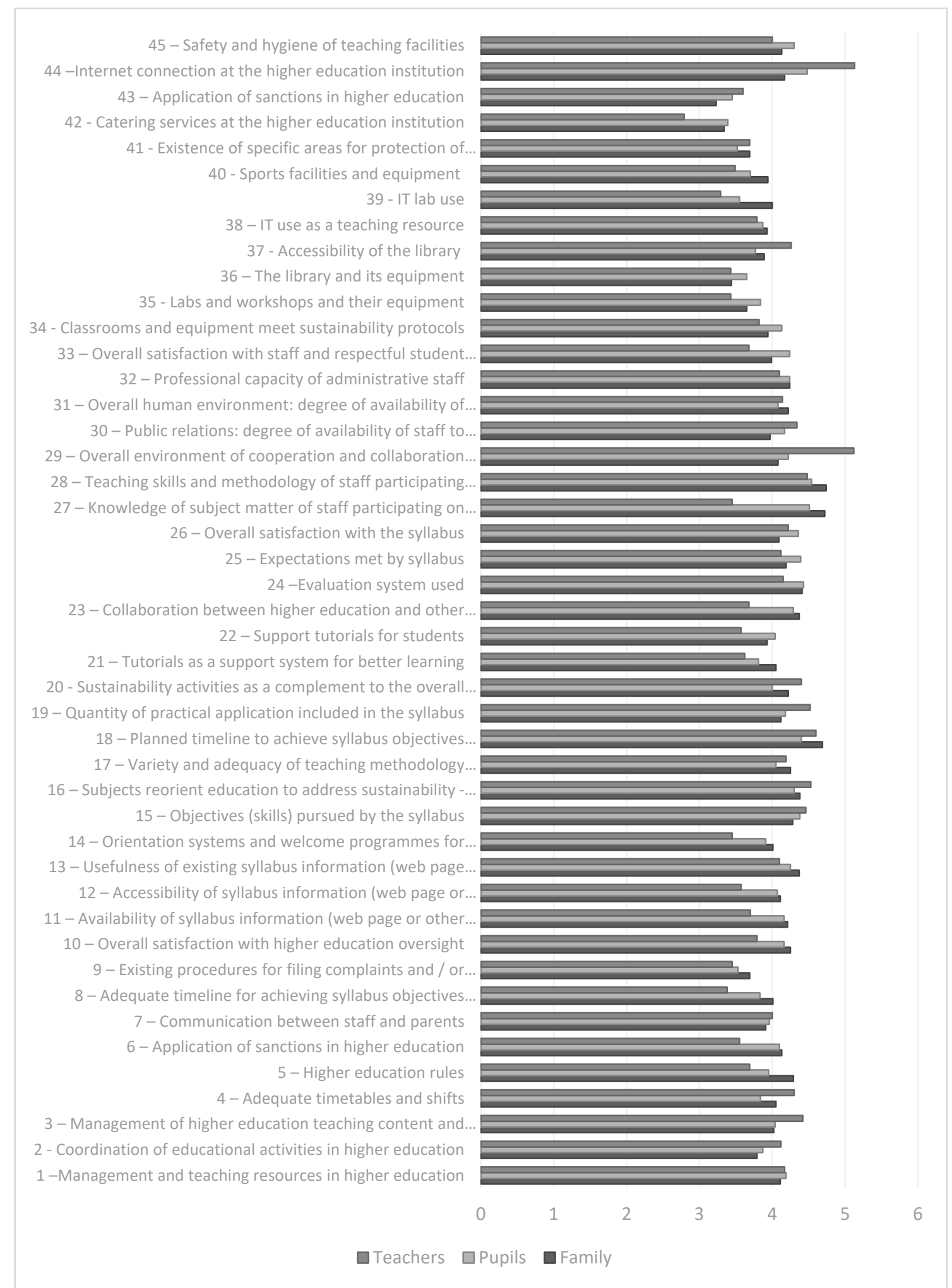

Figure 2. Histogram of the means and standard deviations for QHES by satisfaction and groups.

The majority of existing questionnaires that have been developed to diagnose the quality of higher education ignore sustainability variables, highly implicated groups and satisfaction levels, and, instead, focus solely on quality [36,37]. 
Analysis of educational quality is an inescapable requirement of education. This fact becomes even more relevant in contexts such as higher education, where there is growing demand, student diversity, incomplete information and scarcity of resources [56]. For this reason, the instrument we used established four dimensions (factors) in order to analyse the quality of sustainability variables, implicated groups and satisfaction levels of the setting in which they co-exist. The first dimension is called the management of higher education and teaching resources. It is related to the variety and adequacy of methodology, alongside the formative development of the teachings used in study programs. It is linked with the factor presented by Salas [57] and Yáñez and Soria [58], in that it deals with the achievement of a certain level of quality, in order to meet some of the standards required in teaching and institutional management. The second dimension relates to the coordination of educational activities in higher education. It refers to general satisfaction with staff, facilities and settings, with these being seen as respectful of cooperation and collaboration amongst students. This favours the orientation and management of learning activities, interpersonal relationships, and the channelling of information $[59,60]$. The third dimension describes the management of teaching in higher education through knowledge of the topics included in the study program and the delivery of a planned timetable in order to meet program objectives and the evaluation system used for this. [61-63] argue in support of this dimension, identifying its contribution to the improvement of teaching processes and welcome programs for new students. Finally, the fourth dimension refers to teacher planning and teaching staff in higher education, with this determining the organisation of spaces and timings [61]. Basante, Coronel and Vinueza [64] discuss policies pertaining to the distribution of the load imposed by the academic timetable. This is another way in which resources can be optimised in a sustainable way.

\subsection{Procedure}

\subsubsection{Comprehension Validity of the Instrument}

We conducted a pilot study to check validity. In this study, the instrument was distributed to a sample of 1091 participants (duration of 30 to $60 \mathrm{~min}$ ) to establish the level of comprehension from a qualitative perspective while noting doubts and suggestions.

\subsubsection{Data Collection Procedure}

Questionnaires were administered in a paper format during student and teacher free time in order to avoid interfering with the class timetable of the sample. The questionnaire was administered during March and April 2019. It was approved by the directors of the higher education centres prior to obtaining permission from the Italian Educational Authorities of Naples. Educators collaborated with the research by assisting with participant recruitment. As a consequence, questionnaires were handed out to students, teachers and parents. They were distributed and read together within groups of no more than 30 participants. This enabled us to be able to respond to any question related to understanding and completion of the questionnaire. Participants were not informed about the purpose of the study in order to avoid insincere responses and social desirability. Twelve postgraduate students were present in order to facilitate question understanding and provide any help required. We guaranteed that all gathered information would be used purely for scientific research purposes and that anonymity would be preserved throughout.

\subsection{Data Analysis}

Content analysis of qualitative questions was used for data analysis, with corresponding validation from an expert panel. Quantitative data were analysed in accordance with descriptive statistics and internal consistency estimations. As previously mentioned, this was conducted using SPSS 24.0. Semi-confirmatory factor analysis was conducted using FACTOR Analysis 9.3.1 (IBM SPSS Statistics 
24.0 Chicago, EEUU, 2016) [65]. Confirmatory analysis was carried out using LISREL v9.1 (Scientific Software International, Princeton, New Jersey, 2010) [66].

Data were analysed in order to determine the most appropriate type of statistical procedure to be applied. The Levene test statistic was calculated via a $t$-test for independent samples. This test is appropriate when data indicate homogeneity of variance for both the grouping variables and the variable describing satisfaction. As the sample was sufficiently large in addition to the homogeneity of variance outcome, it was decided that parametric tests were appropriate [67].

A multi-level design for multiple comparisons was followed. Analysis of covariance (ANCOVA) with various factor levels was used to evaluate the difference between participating groups and satisfaction.

\section{Results}

Table 1 and Figure 2 (Appendix A) demonstrate that in the study context, students' families and teachers were identified to be more satisfied with the management of higher education and teaching resources. In addition, families, teachers and students, but particularly teachers who coordinated educational activities in higher education, were found to be highly satisfied with teaching management in higher education. Further, teachers were found to have the greatest level of satisfaction with teacher planning and the planning of teaching staff in higher education.

Table 1 shows the results of the ANOVA conducted on the variables of groups and satisfaction, and the interaction between them. Initially, the multivariate test indicated significant differences and large effect sizes for quality to satisfaction $\left(\mathrm{F}=4.891, p<0.001\right.$ and $\left.\eta^{2}=0.995\right)$, significant differences regarding groups $\left(\mathrm{F}=2.044, p<0.001, \eta^{2}=0.452\right)$, and significant outcomes for the interaction between satisfaction and groups $\left(\mathrm{F}=12.704, p<0.001, \eta^{2}=0.339\right)$.

The multivariate test is a response to the need to simultaneously analyse the relationship between different levels of the same variable with other variables with several levels [68], which allowed us to statistically model the influence of independent groups variables (with three levels) and satisfaction (with five levels) on the coding measured at the individual level. This allowed us to identify the covariance effect of these variables. The results indicate significant differences and large effect sizes with respect to satisfaction, which indicates that in relation to the significance. The sample size or proportion of the variance explained (ANOVA) [69] indicated, with respect to the satisfaction variable, that more than $99.5 \%\left(\eta^{2}=0.995\right)$ of the differences found can be attributed to the effect of quality. Similarly, the results obtained show significant differences with respect to groups as a function of quality, and the sample size (ANOVA) [69] indicated, with respect to the groups variable, that only $45.2 \%\left(\eta^{2}=0.452\right)$ of the differences found can be attributed to the effect of quality, which, although the value is small, is still one-quarter of the population surveyed, which, in social terms and based on the study, is a value to consider. In relation to the square sample size in the interaction between groups of family, teachers and students with respect to satisfaction, almost $33 \%\left(\eta^{2}=0.339\right)$ of the differences found were attributed to the effect of quality.

The fit of the ANOVA outcomes to the data reveals significant associations between the quality of higher education through the pursuit of satisfaction with a focus on sustainability and examines groups and satisfaction. Outcomes related to the existence of specific areas for the protection of sustainability material and resources $(p=0.000)$, classrooms and equipment meeting sustainability protocols $(p=0.000)$, extra-curricular activities targeting sustainability as a complement to the overall formative development of the student $(p=0.000)$, and subjects reorienting education to address sustainability and including it on the syllabus $(p=0.000)$. The quality of higher education through the pursuit of satisfaction, with a focus on sustainability, produced moderate effect sizes in relation to satisfaction. The remaining effects were all small in size. 
Table 1. ANOVA and effect size $\left(\eta^{2}\right)$ for QHES by satisfaction and groups.

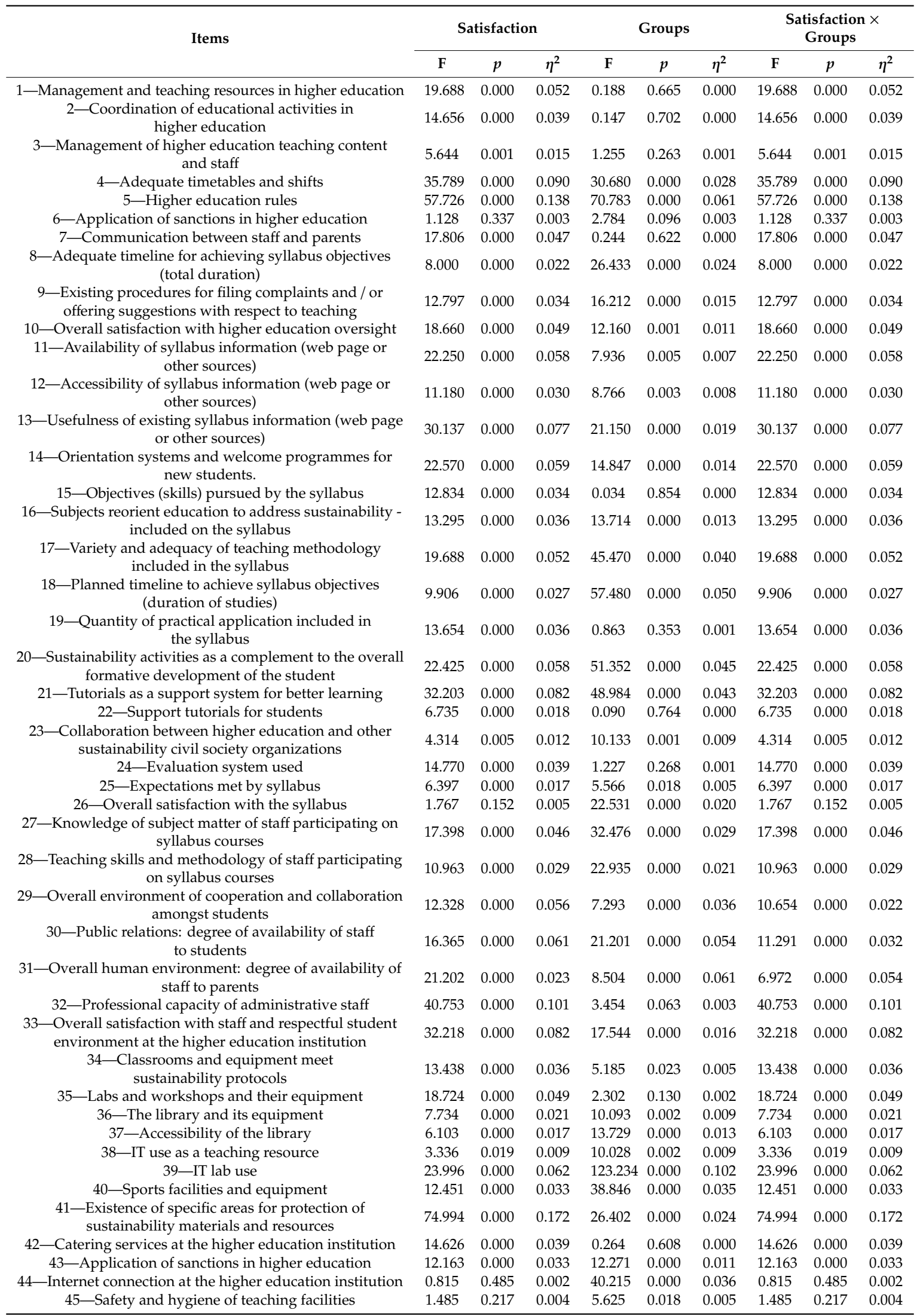

Note: The multilevel linear adjustment was used to reduce the type I error $(\alpha)$. Thus, the $\alpha$-value was divided by

the number of pair comparisons for each ANOVA. 


\section{Discussion}

The present work analysed existing links between general satisfaction and education quality according to various groups (family, students and teachers). It further investigated the relevant role of the sustainability factor in higher education in a community of students undertaking higher education in the south of Italy (Naples). These data corroborate work conducted by [70]. This concluded that collaboration with families is one of the most influential components of satisfaction amongst teachers, with this being one of the aspects of teaching work with which teachers are found to be least satisfied.

Outcomes can also be considered by adopting the focus of the student perspective. González López [71] discuss factors that determine quality in higher education through elements such as skill development for accessing the job market, the working of governing bodies and representatives, student satisfaction with their personal performance, and availability and access to academic information [72,73]. The present research has also uncovered other elements such as facilities (classrooms, catering service, laboratories, library). Facilities enable expectations to be fulfilled in line with those programmed by course prospects. This brings with it strong feelings of personal satisfaction in general and helps achieve a sustainable environment.

In order to carry out the present research, the psychometric evaluation of the questionnaire was performed using the Delphi method. Here, the content validity of the scale was analysed. The panel of 20 experts used existing literature [49] to establish the denomination of variables. It is worth mentioning that the reference studies focus on analysing educational quality in higher education; however, there are some studies which urge caution around the concept of quality in higher education [14]. For this reason, educational institutions are destined to increase and incentivise organisational quality, which brings with it the offer of more satisfactory service to students. Thus, it is of great importance to be able to offer a reliable and empirically tested instrument in order to continue advancing sustainable educational quality and, in this way, optimise resources.

Further analysis conducted on the questionnaire included exploratory factor analysis (EFA), with this providing another indicator of scale reliability. With regards to EFA outcomes, following extraction of common elements, it was found that all elements could be reliably maintained. Thus, the 46 elements established by the expert panel via the Delphi method were retained by the scale. Subsequently, confirmatory factor analysis (CFA) was performed with this confirming reliability of the model by obtaining acceptable indices (CFI and TLI) [51,52]. In addition, construct validity analysis demonstrated consistency with the scale used in the majority of proportions produced for the adapted version. A novel characteristic of the elaboration and validation of this instrument is the inclusion of items specific to sustainability, with these being included in the consideration of management quality as a necessary tool for the examination and improvement of higher education.

A total of $75.70 \%$ of participants reported always agreeing that subjects should be reoriented within education to address sustainability and to ensure it is included in the syllabus. Sustainability is understood as transversal material within the curriculum of higher education teaching, but its inclusion as an integral part of the study plan improves teaching quality. In total, $75.3 \%$ consider that sustainability activities can complement the overall formative development of the student and, thus, must not only be included in the inclusion curricular from a theoretical standpoint. It should also be practiced through activities within both the centre and the community in which it is developed. All of this improves quality. Further, $73 \%$ consider collaboration to be relevant between higher education and other sustainability civil society organizations. This agrees with the idea that the institution is an active social agent whose objective is the overall improvement of teaching. Additionally, $71.5 \%$ consider that, in relation to the promotion of quality education with a focus on sustainability, classrooms and equipment must meet sustainability protocols, which must form part of the higher education institution. Furthermore, $62.50 \%$ reported being in complete agreement with the existence of specific areas for the protection of sustainability-related materials and resources. Indeed, responsible consumption may depend on the characteristics and experiences of individuals, where both the type of training received during schooling and in other settings (such as the family setting), and their uncertainties [74] will 
come into play. Finally, $82.90 \%$ highlighted the importance of internet connections in higher education. This is clear, given we operate in an increasingly globalized world in which the international sphere is becoming more and more relevant. In recent years in Western society, there have been significant changes, seeing the widespread use of information and communication technology and its increase amongst adolescents [66]. This makes internet connections an essential element for the promotion of both quality and development sustainability in higher education.

ANOVA testing demonstrated significant differences and varied effect sizes in the frequency of participants' responses with regards to the quality of higher education, through the pursuit of satisfaction with a focus on sustainability as a function of the grouping variable and satisfaction. Hence, we found differences in the teaching staff group for questionnaire items $2,3,4,7,15,16,19,20,29,30$ and 43 , with items 16 and 20 describing variables that consider sustainability. Within the group of students, the relevant items were $1,22,24,25,33,34,35,36$ and 42 , with the sustainability variable being found in item 34. Finally, the third group which pertains to family, included items 5, 8, 9, 10, 11, $12,13,14,17,18,21,27,28,31,32,37,39,40$ and 41 , with this final item collecting information relevant to sustainability.

It is necessary to highlight some limitations of the present study. Firstly, the sample should be extended to include all higher education centres in the south of Italy. This will broaden knowledge about the quality of higher education as it relates to satisfaction. The focus on sustainability should be retained, with the aim of obtaining further significant results from data collected through the questionnaire developed in the present study. Secondly, we underline the need to conduct further studies that are capable of providing evidence about the effect of satisfaction and relevant societal groups in relation to other experimental variables, which could include, for example, public or private teaching, amongst others. This will be useful in identifying the individuals and social principles required to bring this concept to life. Another of the limitations experienced by the present study was the difficulty in accessing the sample in other southern parts of Italy, although it should be noted that the time needed for data collection was reliable.

\section{Conclusions}

In this sense, far from the results providing only empirical evidence of the advantages of the tools referred to, they also provide an instrument that favours educational quality in a sustainable way $[36,37]$. This can be appreciated in the three groups that were analysed (family, teachers and students) as significant differences were reflected between the various items which relate to sustainable development in higher education. The importance of developing policy statements has been previously demonstrated in a number of studies [75], with the aim of increasing the number and quality of evaluations of educational quality through the lens of sustainability [76] in higher education.

Nevertheless, the role played by a quality education that is geared towards pro-sustainability can no longer be ignored. This includes its economic, social, environmental and organisational dimensions, as these can mark differences in the inter-related circles of learning and performance throughout life [41]. The challenge posed by this to teachers, students and family members alike centres on the struggle to incorporate effective participatory methods within the teaching process. These methods must motivate all players to acquire the knowledge, skills, attitudes and values required to forge a sustainable future [77].

In agreement with that proposed by [78], it is necessary for all those who practice teaching to be critical of their own practice. Self-evaluations of this practice will enable teachers to achieve continuous improvement in their profession [58].

As was previously discussed in the introduction, higher education institutions are associated with advances in knowledge development, which determine the expectations held by society regarding sustainable development. Four factors were obtained in the present study: Management of higher education and teaching resources; coordination of educational activities in higher education; management of teaching in higher education through knowledge of the topics included in the study 
program; delivery of a planned timetable in order to meet program objectives, the evaluation system, and teacher planning and teaching staff in higher education. It is expected that these will help future generations of professionals, students and families to have the required skills to supervise the implementation of this sustainable development.

According to Stephens and Hernández [40], it is expected that higher education institutions lead by example, serving as sustainable practice models for society to emulate. Incorporation of a spirit of sustainability shows how these institutions are transforming their study plans in various disciplines in order to strengthen this sustainable development. This can occur by evaluating the existing curriculum and making subsequent modifications $[79,80]$.

We conclude that the results of the present study will enable further multi-dimensional analysis to be carried out in the future.

Author Contributions: M.d.C.O.-G., M.L.S. and E.M.O.-M., conceptualization. M.d.C.O.-G., methodology and validation, and E.M.O.-M. analysed the data. M.d.C.O.-G. and M.L.S., writing-review and editing. M.d.C.O.-G., supervision. All authors contributed to data interpretation of the analysis. M.d.C.O.-G., M.L.S. and C.F. wrote the paper with significant input from E.M.O.-M. All authors read and approved the final manuscript.

Funding: This research received external funding by Project HUM-983 (ITACA): “Research through transforming learning and contexts.". Principal Researcher: Eva María Olmedo-Moreno.

Conflicts of Interest: The authors declare no conflict of interest.

\section{Appendix A}

Table A1. Means and standard deviations for QHES by satisfaction and groups.

\begin{tabular}{|c|c|c|c|c|c|c|c|}
\hline \multirow{2}{*}{ Items } & \multirow{2}{*}{ Satisfaction } & \multicolumn{2}{|c|}{ Family } & \multicolumn{2}{|c|}{ Pupils } & \multicolumn{2}{|c|}{ Teachers } \\
\hline & & Mean & SD & Mean & SD & Mean & SD \\
\hline \multirow{5}{*}{$\begin{array}{l}\text { 1. Management and teaching resources in } \\
\text { higher education }\end{array}$} & 2 & 2.90 & 0.305 & 3.22 & 0.423 & 4.00 & 1.563 \\
\hline & 3 & 3.96 & 0.852 & 4.11 & 0.800 & 4.30 & 1.341 \\
\hline & 4 & 5.54 & 1.088 & 4.80 & 1.370 & 4.25 & 1.238 \\
\hline & 5 & 6.85 & 0.376 & 5.00 & 1.069 & 3.33 & 1.497 \\
\hline & Total & 4.11 & 1.163 & 4.19 & 1.000 & 4.17 & 1.376 \\
\hline \multirow{5}{*}{$\begin{array}{l}\text { 2. Coordination of educational activities in } \\
\text { higher education }\end{array}$} & 2 & 3.10 & 0.480 & 2.90 & 0.379 & 4.40 & 1.647 \\
\hline & 3 & 3.56 & 0.897 & 3.75 & 0.715 & 4.06 & 1.141 \\
\hline & 4 & 5.25 & 1.294 & 4.32 & 1.071 & 4.25 & 1.438 \\
\hline & 5 & 6.31 & 0.947 & 5.91 & 1.477 & 4.17 & 1.642 \\
\hline & Total & 3.79 & 1.177 & 3.87 & 0.980 & 4.12 & 1.269 \\
\hline \multirow{5}{*}{$\begin{array}{l}\text { 3. Management of teaching content and staff } \\
\text { in higher education }\end{array}$} & 2 & 3.49 & 0.504 & 2.90 & 0.441 & 4.40 & 1.955 \\
\hline & 3 & 3.94 & 0.791 & 3.94 & 0.778 & 4.48 & 1.572 \\
\hline & 4 & 4.73 & 0.962 & 4.47 & 1.042 & 4.38 & 1.708 \\
\hline & 5 & 5.15 & 1.519 & 6.00 & 1.380 & 4.08 & 1.676 \\
\hline & Total & 4.02 & 0.891 & 4.04 & 1.008 & 4.42 & 1.616 \\
\hline \multirow{5}{*}{ 4. Adequate timetables and shifts } & 2 & 3.51 & 0.504 & 2.78 & 0.423 & 4.50 & 1.650 \\
\hline & 3 & 3.85 & 0.466 & 3.85 & 0.671 & 4.36 & 1.478 \\
\hline & 4 & 5.17 & 0.931 & 4.21 & 1.346 & 4.06 & 1.436 \\
\hline & 5 & 6.62 & 0.506 & 4.14 & 0.351 & 4.00 & 1.706 \\
\hline & Total & 4.05 & 0.842 & 3.84 & 0.872 & 4.30 & 1.498 \\
\hline \multirow{5}{*}{ 5. Rules in higher education } & 2 & 2.90 & 0.480 & 3.28 & 0.640 & 4.00 & 0.667 \\
\hline & 3 & 4.19 & 0.638 & 3.99 & 0.576 & 3.65 & 1.029 \\
\hline & 4 & 5.69 & 0.793 & 4.02 & 1.234 & 3.75 & 0.856 \\
\hline & 5 & 6.77 & 0.439 & 4.36 & 0.902 & 3.58 & 0.900 \\
\hline & Total & 4.29 & 1.037 & 3.95 & 0.776 & 3.69 & 0.966 \\
\hline \multirow{5}{*}{ 6. Application of sanctions in higher education } & 2 & 3.08 & 0.281 & 3.12 & 0.516 & 3.50 & 1.080 \\
\hline & 3 & 4.14 & 0.818 & 4.07 & 0.806 & 3.58 & 1.180 \\
\hline & 4 & 4.93 & 0.848 & 4.53 & 1.053 & 3.63 & 0.806 \\
\hline & 5 & 5.00 & 0.408 & 4.73 & 0.883 & 3.33 & 0.985 \\
\hline & Total & 4.13 & 0.909 & 4.10 & 0.908 & 3.55 & 1.103 \\
\hline
\end{tabular}


Table A1. Cont.

\begin{tabular}{|c|c|c|c|c|c|c|c|}
\hline \multirow{2}{*}{ Items } & \multirow{2}{*}{ Satisfaction } & \multicolumn{2}{|c|}{ Family } & \multicolumn{2}{|c|}{ Pupils } & \multicolumn{2}{|c|}{ Teachers } \\
\hline & & Mean & SD & Mean & SD & Mean & SD \\
\hline \multirow{5}{*}{ 7. Communication between staff and parents } & 2 & 3.25 & 0.439 & 2.85 & 0.483 & 4.10 & 0.738 \\
\hline & 3 & 3.79 & 0.578 & 3.94 & 0.610 & 4.02 & 0.715 \\
\hline & 4 & 4.88 & 0.832 & 4.53 & 1.201 & 4.00 & 0.516 \\
\hline & 5 & 5.62 & 0.870 & 4.23 & 0.528 & 3.75 & 0.754 \\
\hline & Total & 3.91 & 0.797 & 3.96 & 0.832 & 4.00 & 0.695 \\
\hline \multirow{5}{*}{$\begin{array}{l}\text { 8. Adequate timeline for achieving syllabus } \\
\text { objectives (total duration) }\end{array}$} & 2 & 2.75 & 0.439 & 2.65 & 0.580 & 3.30 & 0.823 \\
\hline & 3 & 3.98 & 0.658 & 3.77 & 0.805 & 3.31 & 0.795 \\
\hline & 4 & 5.22 & 0.744 & 4.22 & 1.169 & 3.62 & 0.619 \\
\hline & 5 & 5.31 & 0.751 & 5.55 & 1.262 & 3.58 & 0.793 \\
\hline & Total & 4.01 & 0.923 & 3.83 & 1.025 & 3.38 & 0.777 \\
\hline \multirow{5}{*}{$\begin{array}{l}\text { 9. Existing procedures for filing complaints } \\
\text { and / or offering suggestions with respect to } \\
\text { teaching }\end{array}$} & 2 & 3.08 & 0.281 & 2.57 & 0.501 & 3.40 & 0.699 \\
\hline & 3 & 3.59 & 0.819 & 3.55 & 0.864 & 3.46 & 0.770 \\
\hline & 4 & 4.61 & 0.558 & 3.58 & 1.442 & 3.44 & 1.153 \\
\hline & 5 & 5.08 & 1.038 & 4.73 & 0.985 & 3.42 & 0.669 \\
\hline & Total & 3.69 & 0.879 & 3.53 & 1.036 & 3.45 & 0.806 \\
\hline \multirow{5}{*}{$\begin{array}{l}\text { 10. Overall satisfaction with higher education } \\
\text { oversight }\end{array}$} & 2 & 3.69 & 0.464 & 3.45 & 0.504 & 3.80 & 0.422 \\
\hline & 3 & 4.15 & 0.535 & 4.17 & 0.657 & 3.80 & 0.406 \\
\hline & 4 & 5.12 & 0.618 & 4.28 & 0.854 & 3.87 & 0.342 \\
\hline & 5 & 5.46 & 0.660 & 4.68 & 0.646 & 3.67 & 0.492 \\
\hline & Total & 4.25 & 0.688 & 4.16 & 0.721 & 3.79 & 0.407 \\
\hline \multirow{5}{*}{$\begin{array}{l}\text { 11. Availability of syllabus information (web } \\
\text { page or other sources) }\end{array}$} & 2 & 3.31 & 0.464 & 2.73 & 0.506 & 3.70 & 0.675 \\
\hline & 3 & 3.99 & 0.614 & 4.10 & 1.072 & 3.70 & 0.599 \\
\hline & 4 & 5.80 & 1.079 & 4.59 & 1.072 & 3.69 & 0.602 \\
\hline & 5 & 6.77 & 0.439 & 6.00 & 0.690 & 3.75 & 0.452 \\
\hline & Total & 4.21 & 1.041 & 4.16 & 1.180 & 3.70 & 0.587 \\
\hline \multirow{5}{*}{$\begin{array}{l}\text { 12. Accessibility of syllabus information (web } \\
\text { page or other sources) }\end{array}$} & 2 & 3.07 & 0.254 & 2.80 & 0.564 & 3.30 & 0.675 \\
\hline & 3 & 3.94 & 0.538 & 3.95 & 0.722 & 3.60 & 0.492 \\
\hline & 4 & 5.58 & 1.133 & 4.73 & 1.159 & 3.56 & 0.512 \\
\hline & 5 & 6.62 & 0.768 & 5.86 & 0.560 & 3.58 & 0.515 \\
\hline & Total & 4.11 & 0.997 & 4.07 & 0.993 & 3.57 & 0.514 \\
\hline \multirow{5}{*}{$\begin{array}{l}\text { 13. Usefulness of existing syllabus information } \\
\text { (web page or other sources) }\end{array}$} & 2 & 3.68 & 0.471 & 3.60 & 0.496 & 3.80 & 0.422 \\
\hline & 3 & 4.13 & 0.532 & 4.12 & 0.542 & 4.16 & 0.890 \\
\hline & 4 & 5.97 & 1.174 & 4.69 & 0.859 & 3.94 & 0.574 \\
\hline & 5 & 6.46 & 0.877 & 5.73 & 0.631 & 4.17 & 0.835 \\
\hline & Total & 4.37 & 0.984 & 4.25 & 0.737 & 4.10 & 0.821 \\
\hline \multirow{5}{*}{$\begin{array}{l}\text { 14. Orientation systems and welcome } \\
\text { programmes for new students. }\end{array}$} & 2 & 3.00 & 0.000 & 2.85 & 0.362 & 3.10 & 0.994 \\
\hline & 3 & 3.76 & 0.792 & 3.77 & 0.812 & 3.55 & 0.685 \\
\hline & 4 & 5.92 & 1.005 & 4.61 & 1.081 & 3.50 & 0.730 \\
\hline & 5 & 6.62 & 0.768 & 5.36 & 0.492 & 3.00 & 0.853 \\
\hline & Total & 4.01 & 1.188 & 3.91 & 0.981 & 3.45 & 0.753 \\
\hline \multirow{5}{*}{ 15. Objectives (skills) pursued by the syllabus } & 2 & 3.71 & 0.457 & 3.60 & 0.496 & 4.80 & 0.919 \\
\hline & 3 & 4.09 & 0.324 & 4.19 & 0.609 & 4.42 & 0.767 \\
\hline & 4 & 5.34 & 1.077 & 5.16 & .871 & 4.63 & 0.885 \\
\hline & 5 & 6.92 & 0.277 & 5.68 & 0.646 & 4.25 & 0.622 \\
\hline & Total & 4.28 & 0.806 & 4.38 & 0.824 & 4.46 & 0.786 \\
\hline & 2 & 3.81 & 0.393 & 3.18 & 0.385 & 4.80 & 0.632 \\
\hline & 3 & 4.22 & 0.558 & 4.19 & 0.752 & 4.52 & 0.687 \\
\hline $\begin{array}{l}\text { 16. Subjects reorient education to address } \\
\text { sustainability - included on the syllabus }\end{array}$ & 4 & 5.36 & 0.846 & 5.01 & 0.957 & 4.56 & 0.727 \\
\hline & 5 & 6.46 & 1.127 & 5.18 & 0.501 & 4.33 & 0.492 \\
\hline & Total & 4.38 & 0.814 & 4.30 & 0.897 & 4.53 & 0.672 \\
\hline & 2 & 3.36 & 0.483 & 2.95 & 0.597 & 4.60 & 0.966 \\
\hline 17. Variety and adequacy of teaching & 3 & 4.09 & 0.608 & 3.96 & 0.603 & 4.16 & 0.969 \\
\hline 17. varlety and adequacy of teacning & 4 & 5.49 & 0.954 & 4.60 & 0.640 & 4.38 & 1.025 \\
\hline & 5 & 6.92 & 0.277 & 5.36 & 0.492 & 3.83 & 1.030 \\
\hline & Total & 4.25 & 0.961 & 4.05 & 0.771 & 4.19 & 0.986 \\
\hline & 2 & 3.68 & 0.471 & 3.40 & 0.496 & 4.90 & 0.568 \\
\hline 18 Planned ti & 3 & 4.50 & 0.823 & 4.23 & 0.840 & 4.58 & 0.767 \\
\hline 18. Planned timeline to achieve syllabus & 4 & 6.41 & 0.853 & 5.25 & 0.785 & 4.75 & 0.775 \\
\hline & 5 & 6.31 & 0.947 & 5.59 & 0.734 & 4.25 & 0.452 \\
\hline & Total & 4.69 & 1.108 & 4.40 & 0.963 & 4.60 & 0.737 \\
\hline
\end{tabular}


Table A1. Cont.

\begin{tabular}{|c|c|c|c|c|c|c|c|}
\hline \multirow{2}{*}{ Items } & \multirow{2}{*}{ Satisfaction } & \multicolumn{2}{|c|}{ Family } & \multicolumn{2}{|c|}{ Pupils } & \multicolumn{2}{|c|}{ Teachers } \\
\hline & & Mean & SD & Mean & SD & Mean & SD \\
\hline \multirow{5}{*}{$\begin{array}{l}\text { 19. Quantity of practical application included } \\
\text { in the syllabus }\end{array}$} & 2 & 3.25 & 0.439 & 3.15 & 0.700 & 4.50 & 0.707 \\
\hline & 3 & 4.00 & 0.520 & 4.07 & 0.728 & 4.54 & 0.611 \\
\hline & 4 & 5.17 & 0.931 & 4.88 & 0.956 & 4.56 & 0.629 \\
\hline & 5 & 6.54 & 0.776 & 5.09 & 0.294 & 4.33 & 0.778 \\
\hline & Total & 4.12 & 0.865 & 4.18 & 0.885 & 4.52 & 0.634 \\
\hline \multirow{5}{*}{$\begin{array}{l}\text { 20. Sustainability activities as a complement to } \\
\text { the overall formative development of the } \\
\text { student }\end{array}$} & 2 & 3.66 & 0.477 & 2.85 & 0.580 & 4.70 & 0.823 \\
\hline & 3 & 4.08 & 0.534 & 3.94 & 0.653 & 4.43 & 0.799 \\
\hline & 4 & 5.31 & 0.749 & 4.33 & 0.679 & 4.50 & 0.966 \\
\hline & 5 & 5.54 & 0.877 & 5.91 & 0.684 & 3.83 & 0.718 \\
\hline & Total & 4.22 & 0.757 & 4.00 & 0.844 & 4.40 & 0.832 \\
\hline \multirow{5}{*}{$\begin{array}{l}\text { 21. Tutorials as a support system for better } \\
\text { learning }\end{array}$} & 2 & 3.08 & 0.651 & 2.87 & 0.404 & 3.40 & 1.075 \\
\hline & 3 & 3.92 & 0.556 & 3.78 & 0.707 & 3.69 & 0.854 \\
\hline & 4 & 5.15 & 0.847 & 4.26 & 0.710 & 3.50 & 0.894 \\
\hline & 5 & 6.62 & 0.506 & 4.32 & 0.646 & 3.50 & 0.674 \\
\hline & Total & 4.05 & 0.914 & 3.81 & 0.764 & 3.62 & 0.859 \\
\hline \multirow{5}{*}{ 22. Support tutorials for students } & 3 & 3.07 & 0.254 & 3.00 & 0.555 & 3.50 & 0.527 \\
\hline & 4 & 3.83 & 0.642 & 3.93 & 0.840 & 3.58 & 0.665 \\
\hline & 5 & 4.85 & 0.582 & 4.67 & 1.138 & 3.56 & 0.629 \\
\hline & 6 & 6.31 & 0.947 & 5.18 & 0.588 & 3.58 & 0.669 \\
\hline & Total & 3.93 & 0.856 & 4.04 & 0.987 & 3.57 & 0.643 \\
\hline \multirow{5}{*}{$\begin{array}{l}\text { 23. Collaboration between higher education } \\
\text { and other sustainability civil society } \\
\text { organizations }\end{array}$} & 2 & 3.42 & 0.498 & 3.35 & 0.580 & 3.60 & 0.516 \\
\hline & 3 & 4.21 & 0.732 & 4.11 & 0.856 & 3.67 & 0.471 \\
\hline & 4 & 5.80 & 0.996 & 5.18 & 1.320 & 3.75 & 0.447 \\
\hline & 5 & 6.31 & 0.480 & 5.36 & 0.492 & 3.67 & 0.492 \\
\hline & Total & 4.37 & 1.018 & 4.29 & 1.060 & 3.68 & 0.469 \\
\hline \multirow{5}{*}{ 24. Evaluation system used } & 2 & 3.71 & 0.457 & 3.18 & 0.636 & 3.90 & 0.316 \\
\hline & 3 & 4.21 & 0.798 & 4.34 & 1.100 & 4.10 & 1.031 \\
\hline & 4 & 5.63 & 1.049 & 5.26 & 1.292 & 4.81 & 1.559 \\
\hline & 5 & 7.00 & 0.000 & 5.00 & 0.436 & 3.83 & 1.115 \\
\hline & Total & 4.41 & 1.041 & 4.43 & 1.199 & 4.15 & 1.108 \\
\hline \multirow{5}{*}{ 25. Expectations met by the syllabus } & 2 & 3.81 & 0.393 & 3.28 & 0.452 & 4.20 & 0.789 \\
\hline & 3 & 4.06 & 0.669 & 4.26 & 0.952 & 4.12 & 0.572 \\
\hline & 4 & 5.08 & 0.836 & 5.14 & 0.774 & 4.19 & 0.544 \\
\hline & 5 & 5.38 & 0.768 & 5.64 & 0.658 & 4.00 & 0.603 \\
\hline & Total & 4.19 & 0.784 & 4.39 & 1.025 & 4.12 & 0.586 \\
\hline \multirow{5}{*}{ 26. Overall satisfaction with the syllabus } & 2 & 3.17 & 0.378 & 3.63 & 0.490 & 4.10 & 0.316 \\
\hline & 3 & 4.04 & 0.486 & 4.19 & 0.707 & 4.25 & 0.437 \\
\hline & 4 & 5.02 & 0.900 & 5.09 & 0.629 & 4.25 & 0.447 \\
\hline & 5 & 5.31 & 0.630 & 5.64 & 0.790 & 4.08 & 0.515 \\
\hline & Total & 4.09 & 0.746 & 4.36 & 0.831 & 4.22 & 0.438 \\
\hline \multirow{5}{*}{$\begin{array}{l}\text { 27. Knowledge of subject matter of staff } \\
\text { participating on syllabus courses }\end{array}$} & 2 & 3.85 & 0.363 & 3.45 & 0.504 & 3.10 & 0.994 \\
\hline & 3 & 4.50 & 0.862 & 4.40 & 0.986 & 3.43 & 0.784 \\
\hline & 4 & 6.32 & 0.860 & 5.19 & 0.866 & 3.56 & 0.727 \\
\hline & 5 & 6.92 & 0.277 & 5.50 & 0.802 & 3.75 & 0.452 \\
\hline & Total & 4.72 & 1.111 & 4.51 & 1.038 & 3.45 & 0.775 \\
\hline & 2 & 3.03 & 0.183 & 3.08 & 0.474 & 4.50 & 0.527 \\
\hline & 3 & 4.67 & 0.996 & 4.50 & 1.132 & 4.46 & 0.501 \\
\hline $\begin{array}{l}\text { 28. Teaching skills and methodology of staff } \\
\text { participating on syllabus courses }\end{array}$ & 4 & 6.46 & 0.934 & 5.28 & 0.921 & 4.44 & 0.512 \\
\hline particıpatıng on syllabus courses & 5 & 6.31 & 1.182 & 5.00 & 0.436 & 4.67 & 0.492 \\
\hline & Total & 4.74 & 1.294 & 4.54 & 1.161 & 4.48 & 0.502 \\
\hline & 2 & 3.34 & 0.477 & 2.95 & 0.552 & 5.10 & 0.568 \\
\hline rall environment of cooneration and & 3 & 3.92 & 0.452 & 4.05 & 0.654 & 5.10 & 0.597 \\
\hline $\begin{array}{l}\text { 29. Overall environment of cooperation and } \\
\text { collaboration amongst students }\end{array}$ & 4 & 5.34 & 0.734 & 5.06 & 0.472 & 5.00 & 0.632 \\
\hline & 5 & 5.77 & 1.013 & 6.00 & 0.000 & 5.50 & 0.522 \\
\hline & Total & 4.08 & 0.797 & 4.22 & 0.878 & 5.12 & 0.600 \\
\hline & 2 & 2.83 & 0.673 & 3.27 & 0.554 & 4.20 & 0.632 \\
\hline & 3 & 3.88 & 0.462 & 4.03 & 0.622 & 4.42 & 0.885 \\
\hline 30. Public relations: degree of availability of & 4 & 5.08 & 0.596 & 4.85 & 0.794 & 4.13 & 0.885 \\
\hline staff to students & 5 & 6.62 & 0.768 & 5.45 & 0.671 & 4.17 & 0.835 \\
\hline & Total & 3.97 & 0.889 & 4.17 & 0.807 & 4.34 & 0.862 \\
\hline
\end{tabular}


Table A1. Cont.

\begin{tabular}{|c|c|c|c|c|c|c|c|}
\hline \multirow{2}{*}{ Items } & \multirow{2}{*}{ Satisfaction } & \multicolumn{2}{|c|}{ Family } & \multicolumn{2}{|c|}{ Pupils } & \multicolumn{2}{|c|}{ Teachers } \\
\hline & & Mean & SD & Mean & SD & Mean & SD \\
\hline \multirow{5}{*}{$\begin{array}{l}\text { 31. Overall human environment: degree of } \\
\text { availability of staff to parents }\end{array}$} & 2 & 2.66 & 0.477 & 3.13 & 0.516 & 4.30 & 0.483 \\
\hline & 3 & 4.12 & 0.541 & 3.97 & 0.754 & 4.10 & 0.335 \\
\hline & 4 & 5.76 & 0.935 & 4.74 & 0.966 & 4.13 & 0.342 \\
\hline & 5 & 6.92 & 0.277 & 5.00 & 0.436 & 4.33 & 0.492 \\
\hline & Total & 4.22 & 1.080 & 4.08 & 0.883 & 4.14 & 0.372 \\
\hline \multirow{5}{*}{$\begin{array}{l}\text { 32. Professional capacity of administrative } \\
\text { staff }\end{array}$} & 2 & 3.78 & 0.418 & 3.85 & 0.483 & 3.80 & 0.422 \\
\hline & 3 & 3.91 & 0.834 & 4.06 & 0.529 & 4.11 & 0.494 \\
\hline & 4 & 6.00 & 1.130 & 4.95 & 0.738 & 4.13 & 0.500 \\
\hline & 5 & 6.92 & 0.277 & 5.05 & 0.213 & 4.25 & 0.452 \\
\hline & Total & 4.24 & 1.174 & 4.24 & 0.679 & 4.10 & 0.490 \\
\hline \multirow{5}{*}{$\begin{array}{l}\text { 33. Overall satisfaction with staff and } \\
\text { respectful student environment within higher } \\
\text { education }\end{array}$} & 2 & 3.07 & 0.254 & 3.32 & 0.474 & 3.70 & 0.483 \\
\hline & 3 & 3.79 & 0.495 & 4.07 & 0.462 & 3.66 & 0.524 \\
\hline & 4 & 5.46 & 0.750 & 5.05 & 0.460 & 3.69 & 0.479 \\
\hline & 5 & 6.85 & 0.376 & 5.59 & 0.666 & 3.75 & 0.452 \\
\hline & Total & 3.99 & 0.945 & 4.24 & 0.708 & 3.68 & 0.504 \\
\hline \multirow{5}{*}{$\begin{array}{l}\text { 34. Classrooms and equipment meet } \\
\text { sustainability protocols }\end{array}$} & 2 & 3.20 & 0.406 & 2.97 & 0.276 & 3.80 & 0.789 \\
\hline & 3 & 3.77 & 0.538 & 4.01 & 0.597 & 3.82 & 0.647 \\
\hline & 4 & 5.19 & 0.656 & 4.81 & 0.715 & 3.88 & 0.619 \\
\hline & 5 & 6.15 & 0.376 & 5.55 & 0.671 & 3.75 & 0.622 \\
\hline & Total & 3.94 & 0.840 & 4.13 & 0.805 & 3.82 & 0.645 \\
\hline \multirow{5}{*}{$\begin{array}{l}\text { 35. Labs and workshops and their equipment } \\
\text { meet sustainability protocols }\end{array}$} & 2 & 2.44 & 0.623 & 2.60 & 0.632 & 3.40 & 0.699 \\
\hline & 3 & 3.52 & 0.650 & 3.73 & 0.736 & 3.42 & 0.798 \\
\hline & 4 & 4.92 & 0.772 & 4.45 & 0.627 & 3.38 & 0.719 \\
\hline & 5 & 6.69 & 0.630 & 5.36 & 0.492 & 3.58 & 0.669 \\
\hline & Total & 3.65 & 1.045 & 3.84 & 0.886 & 3.43 & 0.762 \\
\hline \multirow{5}{*}{ 36. The library and its equipment } & 2 & 2.83 & 0.378 & 2.57 & 0.501 & 3.40 & 0.699 \\
\hline & 3 & 3.31 & 0.602 & 3.56 & 0.708 & 3.42 & 0.798 \\
\hline & 4 & 4.37 & 0.740 & 4.15 & 0.476 & 3.38 & 0.719 \\
\hline & 5 & 5.31 & 0.751 & 5.14 & 0.351 & 3.58 & 0.669 \\
\hline & Total & 3.44 & 0.792 & 3.65 & 0.809 & 3.43 & 0.762 \\
\hline \multirow{5}{*}{ 37. Accessibility of the library } & 2 & 3.47 & 0.504 & 3.20 & 0.405 & 4.10 & 0.568 \\
\hline & 3 & 3.74 & 0.678 & 3.66 & 0.675 & 4.29 & 0.863 \\
\hline & 4 & 4.88 & 1.115 & 4.32 & 0.834 & 4.38 & 0.957 \\
\hline & 5 & 5.31 & 1.182 & 4.36 & 0.658 & 4.00 & 0.603 \\
\hline & Total & 3.89 & 0.878 & 3.77 & 0.755 & 4.26 & 0.832 \\
\hline \multirow{5}{*}{ 38. Use of IT as a teaching resource } & 2 & 3.17 & 0.378 & 3.05 & 0.597 & 4.00 & 0.816 \\
\hline & 3 & 3.87 & 0.623 & 3.79 & 0.652 & 3.75 & 0.809 \\
\hline & 4 & 4.80 & 0.943 & 4.32 & 0.727 & 4.00 & 0.632 \\
\hline & 5 & 5.15 & 1.519 & 4.77 & 0.922 & 3.67 & 1.231 \\
\hline & Total & 3.93 & 0.824 & 3.87 & 0.762 & 3.79 & 0.836 \\
\hline \multirow{5}{*}{ 39. IT lab use } & 2 & 3.32 & 0.471 & 2.65 & 0.483 & 3.40 & 0.699 \\
\hline & 3 & 3.84 & 0.797 & 3.45 & 0.655 & 3.27 & 0.646 \\
\hline & 4 & 4.93 & 0.848 & 4.15 & 0.919 & 3.38 & 0.619 \\
\hline & 5 & 7.00 & 0.000 & 4.41 & 0.666 & 3.25 & 0.866 \\
\hline & Total & 4.00 & 1.005 & 3.55 & 0.805 & 3.29 & 0.664 \\
\hline & 2 & 2.88 & 0.618 & 2.75 & 0.439 & 3.60 & 0.699 \\
\hline & 3 & 3.82 & 0.825 & 3.62 & 0.796 & 3.42 & 0.701 \\
\hline 40. Sports facilities and equipment & 4 & 5.17 & 0.791 & 4.22 & 0.980 & 3.69 & 0.602 \\
\hline & 5 & 6.31 & 0.480 & 4.77 & 0.752 & 3.58 & 0.669 \\
\hline & Total & 3.94 & 1.058 & 3.70 & 0.906 & 3.49 & 0.685 \\
\hline & 2 & 2.46 & 0.502 & 3.08 & 0.474 & 3.80 & 0.422 \\
\hline & 3 & 3.57 & 0.674 & 3.54 & 0.756 & 3.67 & 0.627 \\
\hline 41. Existence or specinic areas for protection of & 4 & 4.97 & 0.928 & 3.55 & 1.029 & 3.75 & 0.447 \\
\hline & 5 & 6.69 & 0.751 & 3.82 & 0.795 & 3.58 & 0.669 \\
\hline & Total & 3.69 & 1.067 & 3.52 & 0.804 & 3.69 & 0.592 \\
\hline & 2 & 2.19 & 0.393 & 2.75 & 0.439 & 2.90 & 0.738 \\
\hline & 3 & 3.28 & 0.763 & 3.34 & 0.827 & 2.76 & 0.597 \\
\hline 42. Catering services at the higher education & 4 & 4.44 & 0.623 & 3.68 & 1.104 & 2.94 & 0.574 \\
\hline institution & 5 & 5.23 & 0.599 & 4.27 & 0.883 & 2.75 & 0.622 \\
\hline & Total & 3.34 & 0.958 & 3.39 & 0.905 & 2.79 & 0.604 \\
\hline
\end{tabular}


Table A1. Cont.

\begin{tabular}{|c|c|c|c|c|c|c|c|}
\hline \multirow{2}{*}{ Items } & \multirow{2}{*}{ Satisfaction } & \multicolumn{2}{|c|}{ Family } & \multicolumn{2}{|c|}{ Pupils } & \multicolumn{2}{|c|}{ Teachers } \\
\hline & & Mean & SD & Mean & SD & Mean & SD \\
\hline \multirow{5}{*}{ 43. Application of higher education sanctions } & 2 & 2.34 & 0.477 & 2.90 & 0.672 & 3.50 & 0.527 \\
\hline & 3 & 3.21 & 0.408 & 3.44 & 0.792 & 3.63 & 0.534 \\
\hline & 4 & 3.97 & 0.787 & 3.60 & 0.990 & 3.56 & 0.512 \\
\hline & 5 & 4.38 & 0.650 & 3.95 & 0.486 & 3.58 & 0.515 \\
\hline & Total & 3.23 & 0.664 & 3.45 & 0.832 & 3.60 & 0.524 \\
\hline \multirow{5}{*}{$\begin{array}{l}\text { 44. Internet connection at the higher education } \\
\text { institution }\end{array}$} & 2 & 3.95 & 0.222 & 4.18 & 0.549 & 4.90 & 0.876 \\
\hline & 3 & 4.01 & 0.172 & 4.25 & 0.606 & 5.17 & 0.695 \\
\hline & 4 & 4.88 & 0.646 & 5.22 & 0.624 & 5.12 & 0.885 \\
\hline & 5 & 6.00 & 1.000 & 6.00 & 0.000 & 5.08 & 0.515 \\
\hline & Total & 4.17 & 0.534 & 4.48 & 0.768 & 5.13 & 0.718 \\
\hline \multirow{5}{*}{ 45. Safety and hygiene when teaching } & 2 & 3.81 & 0.393 & 3.80 & 0.405 & 4.40 & 0.699 \\
\hline & 3 & 4.01 & 0.231 & 4.15 & 0.522 & 3.96 & 0.756 \\
\hline & 4 & 4.73 & 0.520 & 4.82 & 0.413 & 3.81 & 0.655 \\
\hline & 5 & 5.85 & 0.689 & 5.59 & 0.503 & 4.17 & 0.718 \\
\hline & Total & 4.13 & 0.0503 & 4.30 & 0.634 & 4.00 & 0.742 \\
\hline
\end{tabular}

Note: QHES according to satisfaction and groups.

\section{References}

1. Mateo, J. La evaluación del profesorado y la gestión de la calidad de la educación. Hacia un modelo comprensivo de evaluación sistemática de la docencia. Rev. Investig. Educ. 2000, 18, 7-34.

2. Sierra, J. Factors influencing a student's decision to pursue a communications degree in Spain. Intang. Cap. 2012, 8, 43-60. [CrossRef]

3. United Nations (UN). Post-2015Development Agenda; United Nations: New York, NY, USA, 2015.

4. De La Orden, A. Evaluación del rendimiento educativo y la calidad de la enseñanza. En Instituto de Pedagogía "San José de Calasanz". En La Calidad de la Educación; Consejo Superior de Investigaciones Científicas (CSIC): Madrid, Spain, 1981; pp. 111-131.

5. De La Orden, A. Evaluación y calidad: Análisis de un modelo. Est. Educ. 2009, 16, 17-36.

6. Caballero, J. Satisfacción e Insatisfacción de los Directores Escolares; Grupo Editorial Universitario: Granada, Spain, 2001.

7. Mogensen, F.; Mayer, M.; Breiting, S.; Varga, A. Educación para el desarrollo sostenible. Tendencias; GRAÓ: Barcelona, Spain, 2009.

8. López, M.; Pantoja, A. Escala para valorar la percepción y grado de satisfacción del profesorado de educación primaria de la comunidad autónoma de Andalucía respecto a los procesos tutoriales. Rev. Complut. Educ. 2018, 29, 287-306. [CrossRef]

9. Ham, C.L. Service Quality, Customer Satisfaction, and Customer Behavioral Intentions in Higher Education; D.C.A.: Ann Arbor, MI, USA, 2003.

10. Martínez, M.; García, B.; Quintanal, J. El perfil del profesor universitario de calidad desde la perspectiva del alumnado. Educ. XXI 2009, 9, 183-198. [CrossRef]

11. Pérez, R. Calidad de la educación, calidad en la educación. Hacia su necesaria integración. Educ. XXI 2005, 8, 11-33.

12. Vergara, J.C.; Quesada, V.M. Análisis de la calidad en el servicio y satisfacción de los estudiantes de Ciencias Económicas de la Universidad de Cartagena mediante un modelo de ecuaciones estructurales. Rev. Electron. Investig. Educ. 2011, 13, 108-122.

13. Zineldin, M.; Akdag, H.C.; Vasicheva, V. Assessing quality in higher education: new criterio for evaluating student's satisfaction. Qual. High. Educ. 2011, 17, 231-243. [CrossRef]

14. Larrauri, J.O.; Espinosa, E.M.; Robles, M.I.P. La diversidad semántica y el carácter político de las nociones de calidad en la Educación Superior de México. Rev. Educ. Super. 2015, 44, 85-102. [CrossRef]

15. Barrenetxea, A.M. Modelos de Calidad y Evaluación de la Educación Superior en la Unión Europea. Bilbao. Doctoral Thesis, Universidad del País Vasco, País, Vasco, Spain, 2005.

16. Lago, D.; López, E.; Municio, P.; Ospina, R.; Vergara, G. La Calidad de la Educación Superior.¿Un reto o una utopía? Ed. Ecoe: Bogotá, Colombia, 2013. 
17. Carvalho, S.W.; De Oliveira, M. The role of trust in creating value and student loyalty in relational exchanges between higher education institutions and their students. J. Mark. High. Educ. 2010, 20, 145-165. [CrossRef]

18. Ledden, L.; Kalafatis, S.P.; Mathioudakis, A. The idiosyncratic behaviour of service quality, value, satisfaction, and intention to recommend in higher education: An empirical examination. J. Mark. Manag. 2011, 27, 1232-1260. [CrossRef]

19. Simpson, J.M. Student Perceptions of Quality and Satisfaction in Online Education; The University of Alabama: Tuscaloosa, AL, USA, 2012.

20. Waas, T.; Hugé, J.; Verbruggen, A.; Wright, T. Sustainable Development: A Bird's Eye View. Sustainability 2011, 3, 1637-1661. [CrossRef]

21. Awuzie, B.O.; Abuzeinab, A. Modelling Organisational Factors Influencing Sustainable Development Implementation Performance in Higher Education Institutions: An Interpretative Structural Modelling (ISM) Approach. Sustainability 2019, 11, 4312. [CrossRef]

22. Boström, M. A missing pillar? Challenges in theorizing and practicing social sustainability: Introduction to the special issue. Sustain. Sci. Pract. Policy. 2012, 8, 3-14. [CrossRef]

23. Friman, M.; Schreiber, D.; Syrjänen, R.; Kokkonen, E.; Mutanen, A.; Salminen, J. Steering sustainable development in higher education-Outcomes from Brazil and Finland. J. Clean. Prod. 2018, 186, 364-372. [CrossRef]

24. Godemann, J.; Bebbington, J.; Herzig, C.; Moon, J. Higher education and sustainable development: Exploring possibilities for organisational change. Account. Audit. Account. J. 2014, 27, 218-233. [CrossRef]

25. Madeira, A.C.F.D. Indicadores de Sustentabilidade Para Instituiç õ es de Ensino Superior; Universidad de Oporto: Oporto, Portugal, 2008.

26. Gruber, T.; Fuss, S.; Vossy, R.; Glaser-Zikuda, M. Examining student satisfaction with higher education services. Intern. J. Public Sect. Manag. 2010, 23, 105-123. [CrossRef]

27. Al-Rahimy, S.A.S. Students satisfaction with service quality in Jordanian Universities. Interdiscip. J. Contemp. Res. Bus. 2013, 4, 638-644.

28. Hassan, M.M. Academic satisfaction and approaches to learning among United Arab Emirates University students. Soc. Behav. Pers. 2002, 30, 443-451. [CrossRef]

29. Petruzzellis, L.; d'Uggento, A.M.; Romanazzi, S. Student satisfaction and quality of service in Italian universities. Manag. Serv. Qual. 2006, 16, 349-364. [CrossRef]

30. Chung, E.; McLarney, C. The classroom as a service encounter: Suggestions for value creation. J. Mark. Res. 2000, 19, 491-504. [CrossRef]

31. Yu, Y.-T.; Dean, A. The contribution of emotional satisfaction to consumer loyalty. Int. J. Serv. Ind. Manag. 2001, 12, 234-250. [CrossRef]

32. Alonso-Dos Santos, M. Calidad y satisfacción: El caso de la universidad de Jaén. Rev. Educ. Super. 2016, 45, 79-95. [CrossRef]

33. Resino, J.J.; Chamizo, J.; Cano, E.I.; Gutiérrez, S. Calidad de vida universitaria: Identificación de los principales indicadores de satisfacción estudiantil. Rev. Educ. 2013, 362, 458-484. [CrossRef]

34. Rodríguez, A.; Mármol, M. Liderazgo formativo y desarrollo sostenible de la calidad de la educación. Investig. Desarro. 2009, 17, 192-207.

35. Alvarado, E. Percepción de la calidad educativa: caso aplicado a estudiantes de la Universidad Autónoma de Nuevo León y del Instituto Tecnológico de Estudios Superiores de Monterrey. Rev. Educ. Super. 2016, 45, 55-74. [CrossRef]

36. Harvey, L.; James, W. Fifteen Years of Quality in Higher Education (Part two). Qual. High. Educ. 2010, 16, 81-113. [CrossRef]

37. Enders, J.; Westerheijden, D.F. Quality Assurance in the European Policy Arena. Policy Soc. 2014, 33, 167-176. [CrossRef]

38. Petruzzellis, L.; Romanazzi, S. Educational value: How students choose university: Evidence from an Italian university. Int. J. Educ. Manag. 2010, 24, 139-158. [CrossRef]

39. Didomenico, E.; Bonnici, J. Assessing service quality within the educational environment. Education 1996, 116, 353-360.

40. Stephens, J.C.; Hernandez, M.E.; Román, M.; Graham, A.C.; Scholz, R.W. Higher Education as a Change Agent for Sustainability in Different Cultures and Contexts. Int. J. Sustain. High. Educ. 2008, 9, 317-338. [CrossRef] 
41. De Matos, E.; Leitão, J.; Alves, H. Bridging Intellectual Capital, Sustainable Development and Quality of Life in Higher Education Institutions. Sustainability 2020, 12, 479. [CrossRef]

42. DGES, M. Processo de Bolonha. Available online: https://www.dges.gov.pt/en/node/733 (accessed on 21 December 2019).

43. Pariseau, S.; McDaniel, J.R. Evaluación de la calidad del servicio en las escuelas de negocios. Rev. Intern. Gest. Calid. Fiabil. 1997, 14, 204-218.

44. Chua, C. Percepción de la calidad en la educación superior, Calidad de las universidades australianas. In Proceedings of the 2004 Forum (AUQF), Adelaide, Australia, 7-9 July 2004.

45. Sherry, C.; Bhat, R.; Beaver, B.; Ling, A. Students as customers: The expectations and perceptions of local and international students. HERDSA Conf. 2004. [CrossRef]

46. Correia, S.M.; Miranda, F.J. DUAQUAL: Calidad percibida por docentes y alumnos en la gestión universitaria. Cuad. Gest. 2012, 12, 107-122. [CrossRef]

47. Arambewela, R.; Hall, J. A comparative analysis of international education satisfaction using SERVQUAL. J. Serv. Res. 2006, 6, 141-163.

48. Howell, D.; William, O.; Turner, S. The analysis of missing data. In Handbook Social Science Methodology; Sage: London, UK, 2008; pp. 208-224.

49. Escobar, J.; Cuervo, A. Validez de contenido y juicio de expertos: Una aproximación a su utilización. Avances en Medición. 2008, 6, 27-36.

50. Elosua, P.; Zumbo, B. Reliability coefficients for ordinal response scales. Psicothema 2008, 20, 896-901.

51. González, M.J.; Backhoff, E. Validación de un cuestionario de contexto para evaluar sistemas educativos con Modelos de Ecuaciones Estructurales. RELIEVE. Rev. Electron. Investig. Eval. Educ. 2010, 16, 1-17.

52. Kline, R.B. Convergence of Structural Equation Modeling and Multilevel Modeling; Sage: Thousand Oaks, CA, USA, 2011.

53. Olmedo, E.M.; Berrocal, E.; Olmos, M.C.; Expósito, J. Structural Equations Model (SEM) of a questionnaire on the evaluation of intercultural secondary education classrooms. Suma Psicol. 2014, 21, 107-115. [CrossRef]

54. Bentler, P.; Bonett, D. Significance tests and goodness of fit in the analysis of covariance structures. Psychol. Bull. 1980, 88, 588. [CrossRef]

55. Batista-Foguet, J.M.; Coenders, G.; Alonso, J. Análisis factorial confirmatorio. Su utilidad en la validación de cuestionarios relacionados con la salud. Med. Clin. 2004, 122, 21-27. [CrossRef]

56. Pedraza, L.; Rodríguez, E. El aseguramiento de la calidad: Un imperativo estratégico en la educación universitaria. Ingeniare. Ingeniare. Rev. Chil. Ing. Edit. 2015, 23, 4-5. [CrossRef]

57. Salas, I.; Ordóñez, F. La acreditación desde la perspectiva de sus actores: El caso del Centro Universitario de Ciencias Exactas e Ingenierías de la Universidad de Guadalajara. In En la acreditación de la educación superior en Iberoamérica. La gestión de la calidad de los programas educativos. Tensiones, desencuentros, conflictos y resultados; Rosario, V., Didriksson, A., Marúm, E., Dias, J., Fernández, N., López, F., Villanueva, E., Ríos, J., Eds.; Palibrio: Bloomington, IN, USA, 2013; pp. 237-248.

58. Yáñez, L.M.; Soria, K. Reflexión de Buenas Prácticas Docentes como eje de Calidad en la Educación Universitaria: Caso Escuela de Ciencias Empresariales de la Universidad Católica del Norte. Form. Univ. 2017, 10, 59-69. [CrossRef]

59. Zabalza, M.A.; Zabalza-Beraza, M.A. Competencias Docentes del Profesorado Universitario; Narcea Ediciones: Madrid, Spain, 2003.

60. Vásquez, J.A. Nuevos Escenarios y Tendencias Universitarias. Rev. Investig. Educ. 2015, 33, $13-26$.

61. Zabalza, M.A. Metodología Docente. Revi. Docencia Univ. 2011, 9, 75-98. [CrossRef]

62. Casanova, M.A. El diseño curricular como factor de calidad educativa. Rev. Iberoam. Calid. Efic. Cambio Educ. 2012, 10, 7-20.

63. Mas, O.; Olmos, P. El profesor universitario en el espacio europeo de educación superior. la autopercepción de sus competencias docentes actuales y orientaciones para su formación pedagógica. Rev. Mex. Investig. Educ. 2016, 21, 437-470.

64. Basantes, R.; Coronel, J.; Vinueza, A. Impacto de la evaluación y acreditación de las carreras profesionales ofertadas por la Universidad Nacional de Chimborazo desde la percepción de los estudiantes. Rev. Cienc. Unemi. 2016, 9, 36-47. [CrossRef] 
65. Martínez, A.; Olmos, M.C.; Tomé, M.; Olmedo, E.M. Analysis of Psychometric Properties and Validation of the Personal Learning Environments Questionnaire (PLE) and Social Integration of Unaccompanied Foreign Minors (MENA). Sustainability 2019, 11, 2903. [CrossRef]

66. Olmos, M.C.; López, R.; Mohamed, L. Religion and Sex as Factors of Individual Differences of Reification in an Intercultural-Community-Based Society. Religions 2019, 10, 621. [CrossRef]

67. Warner, N.; Letsky, M.; Cowen, M. Cognitive model of team collaboration: Macro-cognitive focus. In Proceedings of the 49th Annual Meeting of the Human Factors and Ergonomic Society, Orlando, FL, USA, 26-30 September 2005; Sage CA: Los Angeles, CA, USA; pp. 269-273.

68. Andréu, J. El análisis multinivel: Una revisión actualizada en el ámbito sociológico. Metodol. Encuestas 2011, 13, 161-176.

69. Badenes, L.; Frías, D.; Bonilla, A. Un estudio exploratorio sobre el nivel de conocimiento sobre el tamaño del efecto y meta-análisis en psicólogos profesionales españoles. Eur. J. Investig. Health Psychol. Educ. 2018, 7, 111-122. [CrossRef]

70. Larrosa, F.; García-Fernández, J.M. Percepciones de familias y profesorado de Educación Primaria y Secundaria sobre los deberes y derechos docentes y posibilidades de colaboración. Revi. Electron. Investig. Docencia (REID). 2014, 11, 7-28.

71. González, I. Determinación de los elementos que condicionan la calidad de la universidad: Aplicación práctica de un análisis factorial. RELIEVE Rev. Electron. Investig. Eval. Educ. 2003, 9, 83-96. [CrossRef]

72. Nygaard, C.; Belluigi, D.Z. A proposed methodology for contextualised evaluation in higher education. Assess. Eval. High. Educ. 2011, 36, 657-671. [CrossRef]

73. Sproule, R. Student Evaluation of Teaching: A Methodological Critique. Educ. Policy Anal. Archiv. 2000, 50, 1-23. [CrossRef]

74. Olmos, M.C.; Estrada, L.I.; Ruiz, F.; López, R.; Mohamed, L. Making future teachers more aware of issues related to sustainability: An Assessment of best practices. Sustainability 2019, 11, 7222. [CrossRef]

75. Larrán, J.M.; Madueño, J.H.; Calzado, Y.; Andrades, J.A. Proposal for Measuring Sustainability in Universities: A Case Study of Spain. Int. J. Sustain. High. Educ. 2016, 17, 671-697. [CrossRef]

76. Aleixo, A.M.; Azeiteiro, U.; Leal, S. The Implementation of Sustainability Practices in Portuguese Higher Education Institutions. Int. J. Sustain. High. Educ. 2018, 19, 146-178. [CrossRef]

77. Litzner, L.I.; Werner, R. La educación para el desarrollo sostenible en la universidad boliviana. Percepciones del profesorado. Teor. Educ. Rev. interuniv. 2019, 31, 149-173. [CrossRef]

78. Rubio, M.J.; Ruiz, A.; Martínez, F. Percepción del alumnado sobre la utilidad de las actividades de aprendizaje para desarrollar competencias. Revi. Investig. Educ. 2016, 34, 221-240. [CrossRef]

79. Mulder, K.F.; Segalas, J.; Ferrer-Balas, D. How to educate engineers for/in sustainable development: Ten years of discussion, remaining challenges. Int. J. Sustain. High. Educ. 2012, 13, 211-218. [CrossRef]

80. Thomas, I. Challenges for implementation of education for sustainable development in higher education institutions. In Routledge Handbook of Higher Education for Sustainable Development; Barth, M., Michelsen, G., Thomas, I., Rieckmann, M., Eds.; Routledge: London, UK, 2016; pp. 40-55.

(C) 2020 by the authors. Licensee MDPI, Basel, Switzerland. This article is an open access article distributed under the terms and conditions of the Creative Commons Attribution (CC BY) license (http://creativecommons.org/licenses/by/4.0/). 